\title{
First Report of Phytoplasma Infection in Olive Trees (Olea Europea L.)
}

\author{
C. Poggi Pollini', R. Bissani', L. Giunchedi' and E. Vindimian ${ }^{2}$ \\ Authors' address: 'Istituto di Patologia Vegetale, Università degli Studi, via F. Re 8, 40126 Bologna, Italy; \\ ${ }^{2}$ Stazione Sperimentale di San Michele all'Adige, via Mach 10, 38010 San Michele all'Adige, Trento, Italy \\ With 3 figures
}

Received August 8, 1995; accepted November 6, 1995

\begin{abstract}
Abstraet
In the Sarca valley (Trento, north ftaly) the presence of olive trees (Olea Europea L.) with yellow symptoms in a few branches was observed. Some leaves showed diffuse chlorotic mottling affecting almost all the blade. while others showed mottling with green and yellow areas: leaf deformation was also sometimes present. Phytoplasmas were only detected in olive trees with yellow leaves by polymerase chain reaction (PCR) amplification and subsequent restriction fragment length polymorphism (RFLP) analysis. The results obtained suggested a high similarity between this phytoplasma and the elm yellows phytoplasma. This is the first time that a phytoplasma has been reported in the genus Olea.
\end{abstract}

\section{Zusammenfassung}

Erster Bericht ibber eine Phytoplasma-Infektion bei Olivenbäumen (Olea europaea L.)

In Sarca-Tal (Trento. Norditalien) wurden bei Olivenbäumen (Olea europaea L.) in einigen Ästen gelbe Symptome beobachtet. Mehrere Blätter Zeigten eine diffuse chlorotische Scheckung, die fast die ganzen Blattspreiten betraf; andere wiesen Scheckungen mit grünen und gelben Flächen auf, manchmal lagen auch Blattdeformationen vor. Durch Amplifikation mit Hilfe der Polymerase-Kettenreaktion (PCR) und anschließende Analyse der Restriktionsfragmentlängenpolymorphismen (RFLP) wurden Phytoplasmen nur in Olivenbäumen festgestellt, die gelbe Bläter aufwiesen. Die Ergebnisse legten eine starke Ähnlichkeit dieses Phytoplasmas mit dem für die Ulmenvergilbung verantwortlichen Phytoplasma nahe. Dies ist der erste Bericht über das Auftreten eines Phytoplasmas in der Gattung Olea.

\section{Introduction}

Despite the economic importance of olive trees (Olea Europea L.) in the Mediterranean countries, the studies of the infections associated with viruses and phytoplasmas (formerly called mycoplasma-like organisms) can be considered relatively recent. To our knowledge, natural infection by phytoplasmas has never been detected in olive trees. A disease called sickleleaf disorder, characterized by sickle-shaped leaves with lateral distortion and chlorosis has been reported in California, Northern Italy, Portugal and Chile (Thomas, 1958). Sickleleaf disorder was graft-transmitted to a few healthy olive plants, but sap transmission to 16 herbaceous hosts failed and no phytoplasmas or virus particles were observed by electron microscopy (Waterworth and Monroe, 1975). Moreover, symptoms resembling phytoplasma infections such as branch dwarfing with shortened internodes, leaf malformation, branch dieback, leptonecrosis are generally attributed to boron deficiency (Barba, 1993), which is quite diffuse, especially around the Garda lake (Sancassani and De Rossi, 1993).

The introduction of molecular techniques, particularly polymerase chain reaction (PCR) with primers based on the $16 \mathrm{~S}$ rRNA gene provided rapid and sensitive means for detection of phytoplasmas in several herbaceous and woody hosts (Ahrens and Seemüller, 1992). Subsequently, restriction fragment length polymorphism (RFLP) analysis made it possible to group phytoplasmas in seven major phylogenetic clusters, including a few subgroups (Schneider et al, 1993). More recently, the analysis of the $16 / 23 \mathrm{~S}$ spacer regions (SR) of more than 40 phytoplasma isolates revealed a highly variable nucleotide sequence. This region was studied to design strain-specific primers used as reverse PCR primers in combination with $16 \mathrm{~S}$ rDNA primers. These combinations amplified phytoplasmas associated with elm yellows, ash yellows and pear decline (Kirkpatrick et al., 1994).

During autumn/winter 1994, trees with branches with yellow leaves were observed in several orchards of cultivars Frantoio and Leccino, located in the Sarca valley, close to the Garda lake. Some leaves showed diffuse chlorotic mottling affecting almost all the blade whereas other leaves showed mottling with green and yellow areas (Fig. 1). Sometimes malformations of the affected leaves, such as irregular margins occurred. In general, only a few branches of a tree showed these symptoms. but normally all the shoots on these branches had symptomatic leaves. By spring and early summer many of the symptomatic leaves had dropped and the younger leaves showed no symptoms. No other symptoms, such as growth of latent axillary buds, branch die-back or reduced growth, were observed. The incidence of trees with symptoms in the orchards observed was always less than $10 \%$.

This paper reports the detection of phytoplasmas in olive trees using PCR with 'universal' and SR-specific primers and their identification by RFLP analysis of the amplified products. 


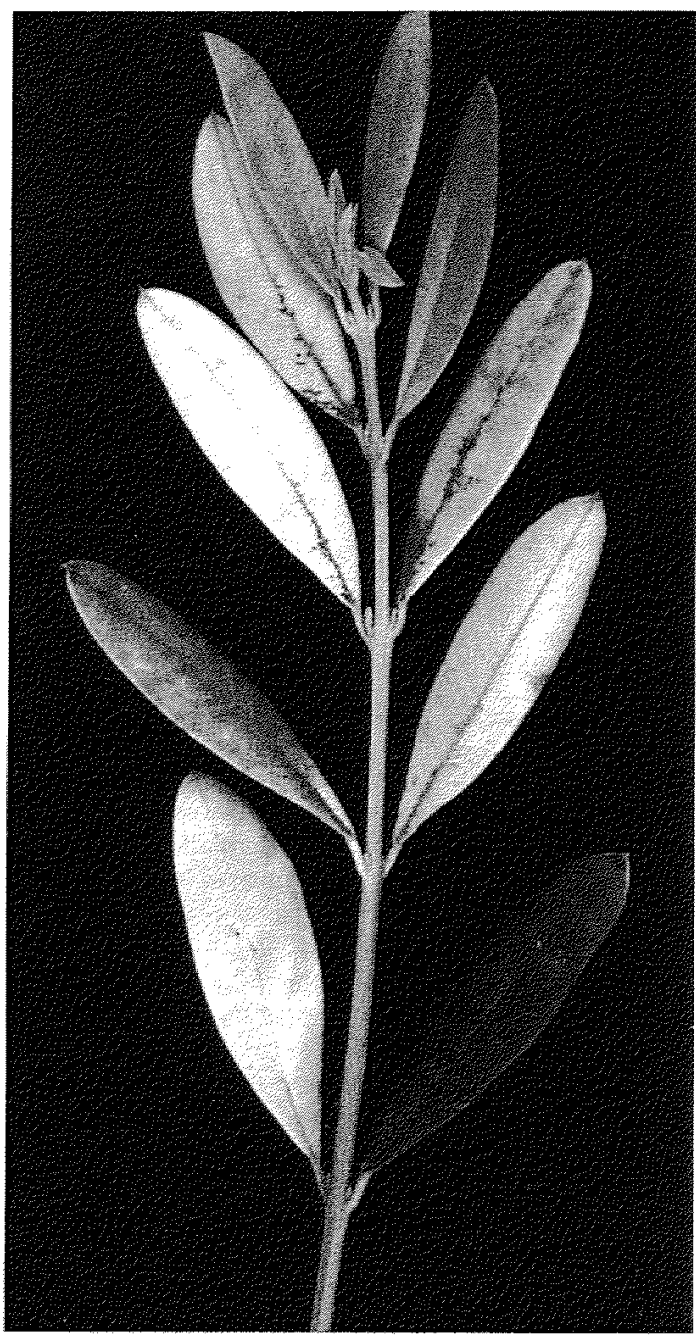

Fig. 1 Shoot of olive tree showing diffuse yellowing and motting

\section{Materials and methods}

DNA was extracted from $0.8 \mathrm{~g}$ of leaf petioles and midribs in late Winter and early Spring five olive trees with yellow leaves, three with yellow leaves and accentuated malformations and five asymptomatic plants were chosen for DNA extraction according to Ahrens and Seemüller (1992). Japanese and Enropean plum trees with leptonecrosis (PLN), cim trees with severe elm witches' broom symptoms - collected in the vicinity of the olve groves - and periwinkles affected with ash yellows phytoplasmas (kindly provided by Dr E. Seemuller) were included as positive controls. The PCR mixture contained $5 \mu$ of DNA preparation (150 ng), $250 \mathrm{~nm}$ of each primer, $100 \mu \mathrm{M}$ of four dNTPs and 1 unit of Tag polymerase (Boehringer Mannheim. Mannheim, Germany). The following primer pairs were chosen: fU5/rU3 which amplified a 880 bp DNA fragment from all phytoplasmas, fO1 rOl which amplified a 1050 bp DNA fragment from all European fruit phytoplasmas (Ahrens et al., 1994), fB/rULWS which amplified at 1630 bo DNA fragment from elm phytoplasmas and BI/PASHYS which amplified a 1630 bp DNA fragment from ash phytoplasmas (Kirkpatrick et al., 1994). The primers chosen were based on the $16 \mathrm{~S}$ rRNA gene (BBI, fOI, fU5, IAT, rOI, rU3) or on the spacer region (rPRUS, rULWS, rASHYS). The PCR parameters were as follows: denaturation 1 min at $95 \mathrm{C}$, annealing 1 min at $55 \mathrm{C}(50 \mathrm{C}$ with BB/rULWS and
BDIASHYS) extension $1.5 \mathrm{~min}$ at $72 \mathrm{C}$ for 35 cycles in a DNA Thermal Cycler 480 (Perkin Elmer, Norwalk. CT, USA). The PCR amplification products were subjetted to electrophoresis on $1 \%$ atgarose gel in TBE buffer ( $45 \mathrm{~mm}$ Tris borate, $1 \mathrm{~mm}$ EDTA, pH 8.0$)$ and staned with ethidium bromide $(\mu \mathrm{g} / \mathrm{ml})$. To characterise the amplified DNAs, from each sample, $20 \mathrm{al}$ of the $\mathrm{PCR}$ reaction products was digested with I fl of Aft I, Rsal and Kpnl restriction endonucleases (Boehringer Mannhem at $37 \mathrm{C}$ for $4 \mathrm{~h}$ and andysed on $10^{\circ} \%$ polyacrylamide gels at $5 \mathrm{~V} / \mathrm{cm}$. Molecular weights were determined using the $1 \mathrm{~kb}$ ladder (BRL, Eggenstein, Germany).

\section{Results and Discussion}

The analysis of the PCR products obtained from olive trees with yellow leaves after 35 cycles revealed the consistent presence of two DNA fragments of approxmately 880 bp and 1630 bp using primer pairs fU5/rU3 and BBI rULWS (Fig. 2). No DNA amplification was observed with the other primer pairs or with DNA samples from olive trees with yellow leaves and accentuated malformations or from asymptomatic olve trees. Positive controls were amplified by appropriate primer pairs. Ain digestion of amplffied fragments with fU5/rU3 from affected olive trees produced an identical restriction profile-- two ragments of 615 and $247 \mathrm{bp}$-similar to that obtaned from elm and ash phytoplasmas. All isolates showed no Kpnl sites, as predicted (Schneider et al., 1993). RFLP analysis of PCR products, amplified with BI/rULWS, provided better identification of the phytoplasmas recovered from olive trees. Alul digestion gave six fragments $(693,254,247,232,130$ and 76 bp; Fig, 3$)$. a pattern identical to that obtained from eln phytoplasmas (Schneider et al. 1993. G. Firrao pers. comm.), Rsal digestion also produced a pattem of seven fragments $(760,425,319,73$. 24, 20, 16, 4) as expected for elm phytoplasmas (Schneider et a., 1993). Conversely, the DNA fragments obtained from ash phytoplasmas, amplified wth BBIASHYS and cut with the same endonucleases, were consistently differen.

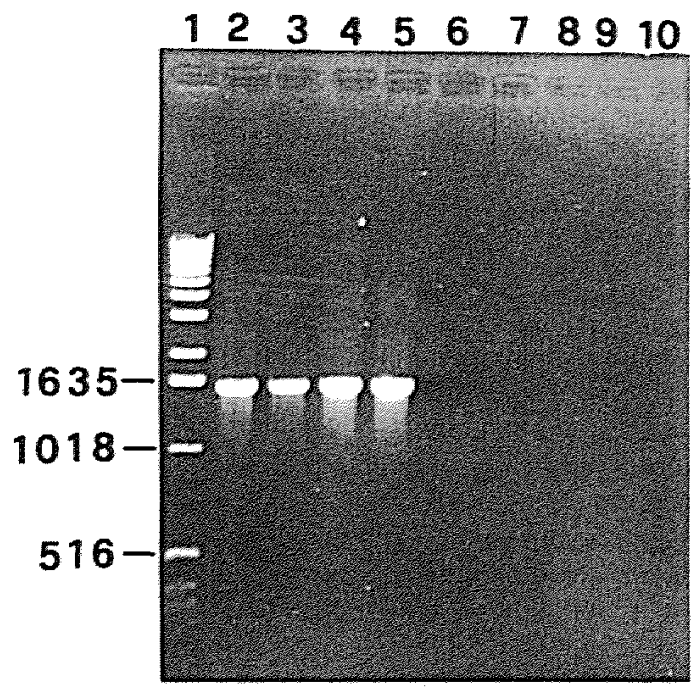

Fig. 2 Agarose gel electrophoresis of PCR products from DNA obtained from: clm trees with witches broom (lane $2 \%$, olive trees with yellow leaves (lanes $3-5$ ), olive trees wh yellow leaves with accentuated malformations (lanes 6 and 7 ), periwinkles aflected by ash yellows (lane 8), asymptomatic olive trees (lanes 9 and 10), Lane 1: 1 kb DNA ladder. Primer pair used was fBI/rULWS 


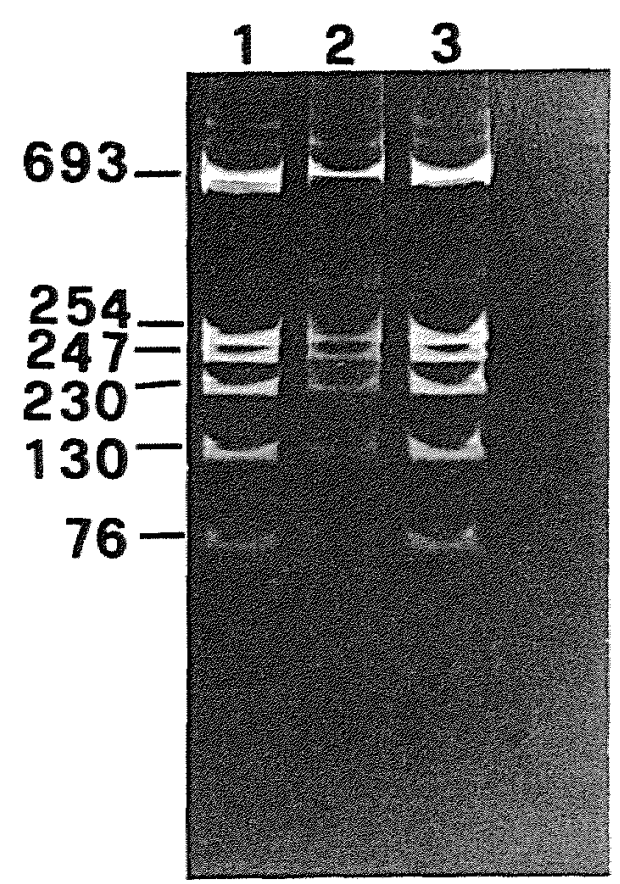

Fig. 3 Restriction protiles after Ah digestion of the PCR products obtained from DNA obtained from DNA isolated from elm trees with witches" brom (lane 1 ) and olve trees wh yelow leaves (lanes 2 and 3). Primer pair used was fBI rULWS

This is the first time that the presence of phytoplasmas has been reported within the genus Olea. The constant detection of phytoplasmas using the PCR technique in olive trees with yellowing symptoms, but not in healthy ones, strongly suggests that the abovementioned symptoms are associated with phytoplasmas. Moreover, all attempts to detect viruses by sap transmission, ELISA and electron microscony gave negative results, indicating phytoplasma aetology. It should be noted that phytoplasmas were not detected in olive trees with yellows associated with severe leaf deformations. However, symptoms such as sickle leaf and leat malformation have been reported in Italy since 1953 and are generally atributed to insect injury. boron deficiency or genetical disorders (Barba, 1993). The data obtained by PCR amplification and RFLP analysis suggest that the phytoplasmas recovered from olve trees can be included in the IV cluster (the EY cluster) described by Schneider al al. (1993), which comprises elm yellows, elm witches broom, rubus stunt and alder yellows phytoplasmas (Schneider et al., 1993. Maurer et al., 1993). Elm yellows is epidemically diffuse in North-east and central Ialy where elm plantations are often in the vicinity of wild blackberry plants (Rubus sp.) with witches broom symptoms (Conti et al, 1987). Elm yellows phyto- plasmas have also been reported in thaly in yellows diseased grapevines around Vicenza (Bianco et al., 1994). To our knowledge the only phytoplasmas recovered to date in Oleaceae were asir yellows, found in several taxa of Fraxinus and in several taxa or Syringa affected with lilac witches broom in North America (Grifiths et al., 1994). Ash yellows phytoplasmas, however, have never been reported in Europe and are closely related to EY phytoplasmas but belong to a different cluster (III) Maurer et al., 1993; Schneider et al., 1993).

Further investigations are necessary to further characterize the phytoplasma examined and to determine the real incidence of this diseatse on olve production and its presence in other regions of Central and Southern ltaly where olive trees are widespread and have a strong economic importance.

\section{Acknowledgements}

We thank Dr B. Kirkpatrick for providing BBI, rULWS and rASHYS sequences. Dr E. Seemuller for providing the other primer sequences and for supplying sources of ash yellows phyloplasma, Dr G. Firrao for helpful suggestions and F. Micheloti, ESAT. Trento for field assistance.

\section{References}

Ahrens, U. E. Seenuiller (1992): Detection of plant pathogenic mycoplasma-like-organisms by a polymerase chan reaction that amplifies a sequence of the $16 \mathrm{~S}$ rRNA gene. Phylopathology 82, 828-832.

Ahrens, U. K. H. Lorenz. R. Berges. B. Schneider, E. Semüler (1994): Universal, cluster-specific, and pathogen-specific PCR amplification of 165 rDNA for detection and identification of mycolasma-likeorganisms. IOM Letr. 3. 250 .

Barba, M. (1993): Virus and virus-like diseases of olve. EPPO Bull 23, 493497

Binneo. P., R. E. Davis. J. P. Prince, A. Fortusini. P. Casati, G. Belli (1994): Eim yellows and aster yellows MLOs associated with a grapeWine disease very smitar to Flavescence doree in Northern Italy. $10 \mathrm{M}$ Lett. 3. $251-252$.

Conti, M. G. D Agostino, L. Mitempergher (1987): A recent epiphytoic of elm yellows in laty. Abstract of VII Congress of the Mediterranean Phytopathological Union. Granada. 1987. 208209.

Grifths, H. M.. A. W. Sinclate, E. D. Gumdersen, I-M. Lee. E. R. Davis 1994): Chafacterization of mycoplasmalike organisms detected in plants in the vicinity of natural outbreaks of ash yellows and elm yellows in North America. IOM Lett. 3, 259 260.

Kimpatrick, B., C. Smart, C. Blomquist, L. Guerta, N. Hartison, U. Ahrens. K. H Lorenz. B. Schneider, E. Seemuller (1994): Identification of MLO strain-specific primers obtatned from $1623 \mathrm{~S}$ rRNA spacer sequences. JOM Lett. 3. 261, 262.

Mutrer. R.. E. Seemüler. W. A. Sinclair (1993): Genetic relatedness of mycoplasmalike organisms affecting elm. alder and ash in Europe and North America. Phytopathol. 83,971-976.

Sancassani. P., M. De Rossi (1993): Avversità dellolivo. Scheda tecnicat. Osservatorio per le malattie delle piante. Regione Veneto.

Schneider, B., U. Ahtens. B. C. Kirkpatrick, E Seemüler (1993): Ciassification of plant-pathogenic mycoplasma-like organisms using restriction-site analysis of PCR-amplified 165 rDNA, 3. Gen. Microbiol 139. $519-527$.

Thomas, H. E 1958: Sickle leaf of olve. Plant Dis. Rep. 42.1154.

Waterworth. H. E., R. L. Monroe. 1975. Graft transmission of olive sickle disorder. Plant Dis. Rep. 59. $360 \% 367$. 
This document is a scanned copy of a printed document. No warranty is given about the accuracy of the copy. Users should refer to the original published version of the material. 